Lieutenant Walter Hyde Hills, R.A.M.C., on June 23rd, at Cawnpore, India, aged 28 years. He entered the service as a lieutenant in July, 1904.

\section{ARMY ADMINISTRATION.}

At the moment of writing the air is full of unauthenticated rumours regarding the changes and economies about to be carried out in the army and political interest is, so to say, on the tiptoe of expectancy to learn what these are to be and what, in short, is to be our future army policy. The Secretary for War will be making his statement in the House just as we are going to press and consequently too late for us to notice whether any changes affecting the army medical services are announced. As it happens the unrest which has arisen in both North and South Africa at the present moment must be a source of some embarrassment to a statesman bent on carrying out any big and bold scheme of army economy.

\section{Strike of Hospital StafFs.}

Under the above heading the correspondent of the Standard describes a remarkable state of affairs at Odessa. He writes that at noon yesterday (July 7th) "the whole attendant staffs, numbering 760, including the cooks, of the city hospitals, declined to proceed with their work and abandoned 3000 patients. The strikers carried off the keys, stores, medicaments, \&c., and fearing their violence the hospitals were surrounded by the military. The doctors and voluntary helpers in the hospital are praiseworthily doing their utmost to minimise the patients' sufferings. This strike is reprobated by the public."

The Naval Medical Supplemental FuNd.

At the quarterly meeting of the directors of this fund held on July 10th, Sir J. N. Dick, K.C.B., being in the chair, the sum of $£ 55$ was distributed among the several applicants.

\section{Cortespondente.}

"Audi alteram partem."

\section{STREET AMBULANCE SERVICE.}

\section{To the Editors of THE LANCET.}

SIRs,-The decision arrived at within the last few days by a Parliamentary Committee to expunge the Ambulance Clauses of the L.C.C. General Powers Bill (1906) will doubtless have the effect of postponing any further action by the County Council for at least 12 months. It is now more than two years since a large proportion of the medical profession resident in London, which includes, as you state in your article last week, most of the leaders and heads of the profession, under the name of the Metropolitan Street Ambulance Association, urged upon our municipal authorities the pressing necessity for an ample and efficient ambulance service for its streets.

Nothing worth speaking of has yet been done to remedy this defect, though the matter has been repeatedly discussed by the London County Council, the Corporation of the City of London, the Metropolitan Asylums Board, and other public bodies. It would be very desirable to know upon what grounds the Committee of the House of Lords threw out the clauses in the Bill to which I have referred. It should be no secret, if progress is to be made, why Parliament refuses to permit the municipal authority of the metropolis to have the necessary enabling powers for dealing with that which for some time past has been, and still is, a grave reflection on the foresight and humanity of its citizens. In a matter of this kind time is pressing, the metropolis continues to grow and additional factors are daily being included amongst those dangers of the streets of which the recent tramcar collision at Highgate is a disastrous example.

I am, Sirs, yours faithfully

July 9th, 1906. REgINALD HaRRISON.

\section{A LOCAL CENSUS.}

To the Editors of THE LANCET.

SIRs, - In connexion with an annotation in THE LANCET of June 30th under the above heading it may be of interest to state that the corporation of this city carried out an unofficial census in 1897 and again this year; the reasons for this were mainly that a sudden wave of prosperity in certain local trades had been accompanied by unwonted immigration and this had rendered the Registrar-General's estimate of the population unreliable. On both occasions the population was found to be underestimated. In the recent census the population was found to be 83,792 , while the Registrar-General's estimate put it at 76,374 . In the light of this information it has been possible to correct the estimated population for 1905; the correction shows that the death-rate was 13.7 instead of $14 \cdot 8$, the birth-rate $26 \cdot 5$ instead of $28 \cdot 9$, and the death-rate from seven infectious diseases $1 \cdot 38$ instead of $1 \cdot 47$.

The method adopted was the division of the city into 88 enumeration areas, each enumerator being furnished with a book; the particulars obtained were the numbers below three years of age, between three and five, between five and 14, and over 14, the number of rooms in each house and the rent. The total expenses of the census amounted to $£ 8710$ s.

The fact of the census being taken on a certain day was extensively advertised and householders were informed that the information obtained would be regarded as confidential and would not be used against them in the event of overcrowding. In spite of this it is clear that such information being voluntary an unofficial census of this sort is liable to greater error than the official census and the error is probably in the direction of under-statement of the population. The great discrepancy shown between the figures obtained and the official estimate affords a very strong argument in favour of a quinquennial census.

I am, Sirs, yours faithfully,

Coventry, July 10th, 1906
E. H. SNELI Medical Officer of Health.

\section{THE TREATMENT OF PULMONARY TUBERCULOSIS. \\ To the Editors of THE LANOWT.}

SIRS,-In my reading of THE LANCET I find that you have very full and clear accounts of what is being done throughout the world in the prevention and treatment of tuberculosis, but apparently the work of the New York Post-Graduate Medical School in this direction has not as yet come under your notice. May I, therefore, present a few facts which perhaps will be of interest to your readers?

In the winter of 1897-98 Dr. John F. Russell of this city asked of the directors of the New York Post-Graduate Medical School that he might be allowed to put a few working people under treatment for tuberculosis in its dispensary. He wished to make an experiment to determine if proper care would cure tuberculosis in the early stages while the patients were still able to be about their daily work. The request was granted. It was arranged that the visits of the patients should be made in the early morn. ing before work hours and in the evening after they had finished. No care of those who could not comply with the condition of two visits daily would be undertaken. In these morning visits the patients were made, in the presence of the nurses and attendants, to take the proper doses of mixed fats, an emulsion made by Dr. Russell, which contains 42 per cent. of fat, made of beef fat, cocoanut, peanut, and olive oil, equal parts, with about two drops of clove oil to each ounce of emulsion. It was also stipulated that the patients should be able to supply themselves with sufficient food of an ordinary quality at their home. There was no supervision of the food, clothes, and habits, except as to expectoration, sleeping in bad air, and so forth. No objection was made to any particular occupation. None but selected cases were accepted. Those having cavities were excluded and also all cases where a large amount of lung tissue was involved, even although there were no large cavities. Cases complicated with other diseases, such as bronchitis, emphysema, diseases of the kidneys, heart, and liver, were also excluded. And no patients were to be admitted whom the supervising committee appointed by the executive committee of the Post-Graduate Medical School and Hospital should regard as doubtful cases. They must be proved by the laboratory to be genuine cases of tuberculosis.

Matters have gone on very well in the dispensary. Although Dr. Russell has given up the care of it it is still maintained by the Post-Graduate School, and carried on by Dr. William Jay Mersereau, who has been for some time an assistant to Dr. Russell, one of the staff of the New York 